\title{
POLSKIE ŻYCIE TEATRALNE W KONTEKŚCIE PROCESÓW EUROPEIZACYJNYCH
}

\author{
Abstract \\ POLISH THEATRICAL LIFE IN THE CONTEXT OF PROCESSES \\ OF EUROPEANISATION
}

Europeanisation understood as a process of assimilation of old and creation of new tasks and standards/rules by the nation states under the influence of European integration affects many areas of our lives. Nor culture or theatre remain indifferent. The possible and existing processes of communitarisation were presented in a wide context showing the distinction of polish theatrical scene to: art and organisation, funding model, international cooperation. The main purpose of the analysis was to present the Polish theatre as an particular model within the European perspective. Its originality is defined by a deep politicization that characterize both artistic project and the practical aspect of management, regulated by legal framework of Polish cultural sphere.

SŁOWA KLUCZE: teatr, europeizacja, kultura, scena, polityka, wolność

KEY WORDS: theatre, europeanisation, culture, stage, politics, freedom

\section{Pojęcie teatru - znaczenia i interpretacje}

Teatr jest jedną z najdonioślejszych sztuk. Dowodów na potwierdzenie tego faktu nie brakuje. Dostarczają go dzisiaj, podobnie jak przed wiekami, bardzo liczne odwołania do teatru w myśleniu potocznym, religijnym, wreszcie naukowym. Liczne metafory teatralne, chętnie przy najrozmaitszych okazjach przywoływane, rzucają światło na te zależności i paralele. Pisano wielokrotnie, że „świat jest teatrem”. Metafora „wielkiego teatru świata”, „theatrum mundi” przedstawia świat jako scenę, zrównuje i zestawia teatr i świat ${ }^{1}$.

\footnotetext{
${ }^{1}$ L. Sokół, Wstęp [w:] J.R. Brown (red.), Historia teatru, Warszawa 2007, s. 1.
} 
Tak pisał Lech Sokół, polski historyk teatru i dramatu. To symboliczne ujęcie ukazuje rangę teatru w panteonie innych sztuk. Unaocznia, jaka siła jest nie tyle w samej materii sztuki scenicznej, ile jak głęboko forma teatru była i jest wykorzystana w otaczającym świecie. To faktyczne zespolenie świata sztucznego, wytworzonego, jakim jest teatr, z rzeczywistością społeczną - bieżącym dniem i codziennością. Konotacje polityczne również nie pozostają obce. Na co dzień mówimy o aktorach życia politycznego - politykach, a o samej grze politycznej - scenie aktywności społecznej. Owe zależności można wykazywać niezwykle szeroko, dochodząc do wniosku, że każde działanie, które nastawione jest na pokaz i posiada odbiorcę (widza), jest swoistym performansem² ${ }^{2}$ Tym samym można uznać, że dochodzi do uniwersalizacji działań teatralnych w codziennym funkcjonowaniu. Teatr jest wszędzie i w każdym z nas. Jako forma społeczna jest otwarty (tak jak my jesteśmy jako pojedyncze jednostki) na przyjmowanie nowych wzorców, standardów i wartości.

Ujmując teatr bardzo wąsko, jako dziedzinę sztuki, należy wskazać coś oczywistego i pewnego. Jego tradycja europejska wyrasta ze starożytnej Grecji, co wiązało się z występami chóralnymi ku czci Dionizosa. Drugim ważnym czynnikiem stały się doświadczenia średniowiecza i obrzędy religijne powiązane z chrześcijańską liturgią. Tradycja kościelnych jasełek czy obrzędów męki Pańskiej, stała się konstytutywna dla kształtowania autonomicznych przedstawień. Początkowo na placach, w domach, aż ostatecznie w dedykowanych salach i budynkach teatralnych. Kluczowy dla rozwoju sztuki scenicznej na kontynencie europejskim stał się przełom XIX i XX wieku wraz z Wielką Reformą Teatru³. Dzięki owym przemianom teatr stał się „,sztuką”, widowisko - „dziełem sztuki teatru”, a reżyser - ,artystą teatru”. Teatr stał się sztuką autonomiczną, w którym nadrzędną funkcję pełnił pełny spektakl będący syntezą - tekstu, scenografii, muzyki, choreografii i światła pod wodzą reżysera. To budowało rangę europejskiej sceny. Kumulacja założeń teoretycznych z doświadczeniem praktycznym obejmowała praktycznie cały kontynent. Od rosyjskich metod pracy z aktorem Konstantego Stanisławskiego i Wsiewołoda Meyerholda, przez reformę moralną sceny polskiej Stanisława Wyspiańskiego, przez praktykę Maxa Reinhardta, aż do założeń intelektualnych Gordona Craiga i Adolphe Appii. Tym samym bez udziału konkretnych instytucji, a za sprawą twórców i teoretyków teatr w sposób praktyczny unifikował się w Europie, akceptując i praktykując założenia wielkiej reformy - nowoczesnego teatru.

Obecnie teatr - jako sztuka i w warstwie ideowej - nie pozostaje obojętny na otaczający świat oraz jego problemy. Dlatego powinien pozostawać wolny i niezależny od władzy. Można go uznać za najbardziej społeczną ze wszystkich sztuk, gdyż w niej jako jedynej dochodzi do bezpośredniego spotkania twórcy i odbiorcy. Nie istnieje żaden pośrednik przekazu. W teatrze zachodzi bezpośrednia interakcja wykonawców i widzów - uczestników zdarzenia teatralnego. Każdy spektakl teatralny to odmienny akt artystyczny realizowany we wspólnocie uczestników scenicznego zdarzenia. Teatr najszybciej i najtrafniej zdoła reagować na zmiany społeczne. Spektakl

2 Por. R. Schechner, Performatyka. Wstę, Wrocław 2006.

${ }^{3}$ Por. K. Braun, Wielka Reforma Teatru w Europie, Wrocław 1984. 
może stać się katalizatorem wydarzeń, ale również stanowić komentarz do codzienności. Sztuka teatralna jest otwarta - z jednej strony wielokrotnie wchodzi w dyskurs ze światem zewnętrznym, stając się sztuką polityczną, a z drugiej jest autonomiczna, gdyż wyraz artystyczny staje się nadrzędny. Jednak owo ujęcie wydaje się polemiczne ze względu na fakt, że każda forma posiada znamiona zmiany i w ten sposób staje się wypowiedzią wobec świata otaczającego. Tym samym każde działanie teatralne posiada konotacje społeczne (zawężając - polityczne). Piotr Pawlenski, rosyjski performer i akcjonista, traktując politykę jako urzeczywistnianie kontroli władzy, dosadnie zauważał:

Artyści powinni uświadomić sobie swoją polityczną odpowiedzialność. Sztuka to sfera odpowiedzialności, permanentnej walki. Artysta od początku powinien sobie uświadomić permanentny charakter tej walki ${ }^{4}$.

Gdy rozpatrujemy powyższe przykłady, z jednej strony wskazujące człowieka w teatrze życia codziennego, wykorzystując tytuł publikacji Ervinga Goffmana ${ }^{5}$, samoczynny rozwój teatru w początkach XX wieku czy charakter współczesnej sceny, rodzi się pytanie: Czy niezbędne są konkretne działania, próby czy też instytucje dla kształtowania sztuki teatralnej? Czy w ogóle ta dziedzina życia społecznego podlega jakimkolwiek regulacjom i powinna posiadać jakąkolwiek dominantę zmierzającą do ujednolicania czy też standardyzacji? Odpowiedź jest jednoznacznie negatywna. Sztuka umiera, gdy staje się zniewolona i podporządkowana. $Z$ wolnej i niezależnej staje się emblematem władzy wykorzystanym do funkcji agitacyjnej.

Termin teatr posiada także inne interpretacje, które są istotne i ważne z punktu widzenia niniejszego opracowania. 1) To budynek specjalnie urządzony i przeznaczony do prezentacji spektakli dramatycznych, lalkowych, operowych czy baletowych. 2) Teatr to swoista instytucja społeczna (publiczna), która ma określony zespół artystyczny, administracyjny i techniczny kierowany przez dyrektora placówki. Powołana przez organizatora, który jest mecenasem jej działalności. 3) To organizm wpisany w konkretną rzeczywistość społeczną oraz zarządzany na podstawie norm i zasad określonych przez państwo. Teatr podlega konkretnemu prawu dedykowanemu sferze kultury. 4) To instytucja podejmująca szeroką współpracę w płaszczyźnie krajowej i zagranicznej z innymi podmiotami działającymi w tej sferze życia społecznego.

Typologia polskiego reżysera teatralnego i teatrologa, Kazimierza Brauna, kumuluje zawarte powyżej cechy: 1) Teatr to proces międzyludzki, kształtowany artystycznie. 2) To sztuka żywego człowieka. 3) Jest sztuką ludzkiej zbiorowości składającej się z aktorów i widzów. 4) Widowisko to podstawowy wytwór teatru, od XX wieku nazywane dziełem sztuki. 5) Życie społeczne wykazuje cechy teatralizacji, czyli wykorzystywania elementów teatru do obrzędów i rytuałów społecznych powiązanych z polityką, sportem czy muzyką. 6) Każdy poszczególny teatr jest

${ }^{4}$ P. Pawlenski, Sztuka polityczna, rozmawiał Artur Żmijewski [w:] J. Kutyła, P. Walaszkowski (red.), Pawlenski, Warszawa 2016, s. 20.

${ }_{5}^{5}$ E. Goffman, Człowiek w teatrze życia codziennego, Warszawa 1981. 
strukturą społeczną, stanowi bowiem grupę ludzi jednoczących się w konkretnym celu. Staje się on instytucją społeczną, która posiada zespół ludzi, właściwą siedzibę oraz fundusze umożliwiające jego funkcjonowanie ${ }^{6}$.

Zaprezentowane cechy ukazują głęboki związek z materią polityki. Z jednej strony wynika to z zainteresowania sceny życiem bieżącym, a z drugiej - z aktywności państwa w sferze kultury. Państwa europejskie w odmienny sposób (na szczeblu centralnym i lokalnym) kształtują politykę kulturalną. Założenia mogą być bardzo różne: od budowania w tym zakresie polityki publicznej - do silnych tendencji aktywności władzy, łącznie z próbami ograniczania swobody wypowiedzi, tak jak w Polsce ${ }^{7}$. Każdorazowo jednak państwo jest podmiotem zaangażowania w tę sferę życia społecznego. Tym samym włączenie kraju w struktury europejskie ma swoje wymierne konsekwencje dla kultury (w tym teatru).

W tym aspekcie należy poczynić zastrzeżenie, które jednocześnie stanowi tezę opracowania. Mimo obecności naszego kraju w strukturach europejskich nie istnieje, a faktycznie jest niemożliwy, zauważalny proces absorbcji wzorców i rozwiązań w dziedzinie teatru (jako sztuki). Jest ona niezależna i autonomiczna oraz kształtuje się indywidulanie w poszczególnych państwach. Natomiast można wskazać pewne tendencje integracyjne, gdy teatr rozpatrujemy jako instytucję społeczną, obiekt architektoniczny czy też formę różnorodnej kooperacji międzynarodowej.

\section{Europeizacja a teatr}

Europeizacja to termin szeroko używany i wykorzystywany w debacie publicznej. W gąszczu definicyjnym badacze wskazują na ujęcie rozszerzające (sensu largo), przyjmując, że jest to: „rozwijający się w czasie proces, polegający na złożonej interakcyjności zmiennych, skutkujący zróżnicowanymi, współzależnymi, a nawet sprzecznymi efektami"». Takie ujęcie dużo nie wyjaśnia w odniesieniu do konkretnych dziedzin życia społecznego. Naukowa refleksja ukazuje osiem wymiarów europeizacji. Kilka z nich wydaje się adekwatnych do sfery kultury. Należą do nich europeizacja w znaczeniu: socjologicznym - przyjmowanie wzorców i zwyczajów europejskich, stylu życia, norm, krzewienie tożsamości europejskiej czy też przyjmowanie i respektowanie fundamentalnych zasad wolności, demokracji i praw człowieka; politycznym - wpływanie na procesy, struktury i funkcje, wykorzystywanie i włączanie rozwiązań europejskich do polskiego modelu zarządzania kulturą, oraz prawnym - posiłkowanie się regulacjami normatywnymi dla życia kulturalnego9.

${ }^{6}$ Zob. K. Braun, Kieszonkowa historia teatru na świecie w XX wieku, Lublin 2000, s. 12-16.

7 Por. D. Przastek, Ograniczenia wolności wypowiedzi artystycznej w Polsce po roku 1989. Przypadek teatru, „Kwartalnik Naukowy OAP UW e-Politikon” 2016, nr 18.

${ }^{8}$ Ujęcie Kennetha Dysona, za: K. Wach, Wokót pojęcia europeizacji, „Horyzonty Polityki” 2010, nr 1, s. 196; tenże, Wymiary europeizacji i jej kontekst, Zeszyty Naukowe Uniwersytetu Ekonomicznego w Krakowie 2011, nr 852, s. 30.

9 Szerzej o wymiarach europeizacji: tamże, s. 37. 
Rozpatrując kontekst praktyczny, a nie tylko teoretyczny, przyjąłem następujące ujęcie europeizacji: to „proces adaptacji starych oraz powstawania nowych zadań, norm i struktur państw narodowych pod wpływem integracji europejskiej”"10. To wszelkiego rodzaju rezultaty powstałe jako następstwo procesu konsolidacji europejskiej. Zasada posiada swoisty dualny charakter. Z jednej strony to wpływ instytucji państwa narodowego czy też jego polityki na europejską wspólnotę. $Z$ drugiej to wpływ procesu integracji europejskiej oraz Unii Europejskiej na państwo narodowe ${ }^{11}$. Przyjmując owe uwagi i przekładając na sferę kultury (teatru), możemy zauważyć również ową podwójną interpretację. Według aktów prawnych sfera kultury pozostaje $\mathrm{w}$ dyspozycji państw narodowych i nie podlega szczególnym restrykcjom ujednolicenia. Zgodne z ust. 1 art. 167 Traktatu lizbońskiego ${ }^{12}$ : „Unia przyczynia się do rozkwitu kultur Państw Członkowskich, w poszanowaniu ich różnorodności narodowej i regionalnej, równocześnie podkreślając znaczenie wspólnego dziedzictwa kulturowego" "13. Tym samym różnorodność i wspieranie rozkwitu kultur narodowych buduje wspólną europejską tożsamość. Wkład i rozwój autonomicznej sztuki teatralnej w poszczególnych państwach kształtuje europejską rangę sceny. Owa uwaga jest zgodna ze wskazaną tezą, że nie ma możliwości unifikacji w sferze sztuki, która kształtuje się dzięki niezależności i kreatywności twórców. Jednocześnie, zgodnie ze wskazanym dokumentem, Unia zmierza do zachęcania, pobudzania i tylko gdy jest to niezbędne - do wspierania i uzupełniania owych działań również w dziedzinie twórczości artystycznej. Podkreślenie zasady subsydiarności ma istotny wpływ na rozwój instytucji teatralnych (budynki, administracja) oraz uaktywnienie współpracy między państwami w tym zakresie. Służyły i służą temu następujące programy: Kultura, a także realizowany w latach 2014-2020 Kreatywna Europa, złożony z trzech komponentów: MEDIA, Kultura i część międzysektorowa.

Uzupełnienie może stanowić dedykowane kulturze ustawodawstwo Rady Europy. Europejska Konwencja Kulturalna, sporządzona w Paryżu 19 grudnia 1954 roku ${ }^{14}$, określa podstawy działania i współpracy państw członkowskich organizacji w tej sferze życia społecznego. Dokument powstał w celu osiągnięcia większej jedności członków, aby chronić i realizować ideały oraz wartości stanowiące wspólne dziedzictwo państw naszego kontynentu. Istotne było wskazanie, że nie istniały żadne tendencje unifikacyjne w sferze kultury, a ochrona i pomoc w rozwoju narodowych kultur miały stanowić wkład we wspólne dziedzictwo kulturalne Europy (art. 1). Analogicznie jak w przypadku przepisów traktatowych UE, współpraca i wsparcie działalności kulturalnej w ramach projektów będących przedmiotem

${ }^{10}$ S. Sulowski, Państwo narodowe w procesie integracji europejskiej [w:] K.A. Wojtaszczyk (red.), Integracja europejska. Wstęp, Warszawa 2006, s. 72.

${ }_{11}$ Szerzej: tamże, s. 72-80.

${ }_{12}$ Traktat z Lizbony zmieniajacy Traktat o Unii Europejskiej i Traktat ustanawiajacy Wspólnotę Europejska sporzadzony w Lizbonie dnia 13 grudnia 2007 r.

13 Art. 167 za: Traktat Lizboński, wprowadzenie J. Sozański, Warszawa-Poznań 2010, s. 100101. Przepis to prawie jednoznacznie powielenie art. 128 Traktatu z Maastricht i art. 151 Traktatu amsterdamskiego.

${ }^{14}$ Europejska Konwencja Kulturalna z dnia 19 grudnia 1954 r., Dz.U. 1990 nr 8 poz. 44. 
ogólnoeuropejskiego zainteresowania stanowiły istotny wkład w kształtowanie poszanowania kultur europejskich (art. 3) i wolne były od kategorii narzucenia oraz państwowego kreowania form owej partycypacji.

\section{Podstawy prawne życia teatralnego w Polsce}

W zakresie określenia funkcjonowania podmiotów w sferze kultury (w tym teatrów) zasadniczą rolę odgrywa Ustawa o organizowaniu i prowadzeniu działalności kulturalnej z 25 października 1991 roku, z najbardziej głębokimi zmianami wprowadzonymi 31 sierpnia 2011 roku $^{15}$. Akt prawny wskazuje główne cele działalności kulturalnej - tworzenie, upowszechnianie, ochronę, sprawowanie mecenatu oraz wsparcie finansowe. Według dokumentu naczelnym zadaniem państwa, wypełnianiem polityki kulturalnej, w obecnym czasie jest wspieranie finansowe różnych form działalności kulturalnej i twórczości artystycznej. Dotyczy to zarówno instytucji publicznych, jak i niepublicznych.

W myśl przepisów podmioty, które mogą prowadzić działalność kulturalną, w tym teatralną, to: 1) osoby prawne (podmioty państwowe, komunalne, prywatne, organizacje pozarządowe - stowarzyszenia rejestrowe, fundacje), 2) osoby fizyczne (każdy człowiek) oraz 3) jednostki organizacyjne nieposiadające osobowości prawnej (stowarzyszenia zwykłe) ${ }^{16}$. Ważna stała się regulacja w płaszczyźnie instytucji kultury. Podmiotami właściwymi do organizacji działalności kulturalnej są: właściwy minister oraz kierownicy urzędów centralnych, którzy mają prawo tworzenia 1) państwowych instytucji kultury, oraz jednostki samorządu terytorialnego, które powołują - 2) samorządowe instytucje kultury. Prowadzenie działalności kulturalnej jest zadaniem własnym jednostek samorządu terytorialnego o charakterze obowiązkowym. W zakresie powoływania szefa placówki artystycznej wyeliminowano możliwość nominowania dyrektora na czas nieokreślony. Powołuje go organizator na czas określony - od 3 do 5 sezonów artystycznych. Przed powierzeniem funkcji dyrektora zostaje zawarta umowa, która określa warunki organizacyjno-finansowe oraz program działalności instytucji.

Założenia nowelizacji Ustawy o organizowaniu i prowadzeniu działalności kulturalnej zmierzały w kierunku zwiększenia autonomii instytucji kultury względem organu założycielskiego. Podstawową zasadą tych relacji miały być: reguła samodzielności programowej określonego statutem profilu instytucji oraz podstawowa wartość demokratycznych państw europejskich - jej wolność artystyczna. Jednak nie

15 Ustawa z dnia 25 października 1991 r. o organizowaniu i prowadzeniu działalności kulturalnej, Dz.U. 2012 poz. 406 (Obwieszczenie Marszalka Sejmu Rzeczypospolitej Polskiej z dnia 26 marca 2012 r. w sprawie ogłoszenia jednolitego tekstu ustawy o organizowaniu i prowadzeniu działalności kulturalnej).

${ }^{16} \mathrm{~W}$ celu powierzenia zarządzania instytucją kultury osobie fizycznej lub prawnej stosuje się przepisy: Ustawa z dnia 29 stycznia 2004 r. - Prawo zamówień publicznych, Dz.U. $2010 \mathrm{nr} 113$ poz. 759 z późniejszymi zmianami. (Obwieszczenie Marszałka Sejmu Rzeczypospolitej Polskiej z dnia 8 czerwca 2010 r. w sprawie ogłoszenia jednolitego tekstu Ustawy-Prawo zamówień publicznych). 
ma żadnej prawnej gwarancji, że dyrektor placówki kultury może realizować swój program całkowicie niezależnie, bez presji i wpływu organów zarządzających. Ustawodawca nie zagwarantował formalnie wolności wypowiedzi artystycznej oraz prawa do swobody twórczej.

Podległość instytucji kultury organowi prowadzącemu działalność kulturalną istnieje również ze względu na system powoływania i odwoływania dyrektorów. Tylko w części instytucji przewidziano przeprowadzanie konkursów, ale i od tej zasady jest możliwe odstępstwo. Skład komisji wydaje się polemiczny, bowiem większość mogą w niej posiadać urzędnicy, którzy nie znają materii artystycznej. W państwowych instytucjach kultury nie ma obligatoryjnego obowiązku przeprowadzania konkursu. W samorządowych instytucjach kultury przewiduje się konkursy, ale tylko w placówkach umieszczonych w wykazie ministra do spraw kultury i ochrony dziedzictwa narodowego ${ }^{17}$. W części placówek samorządowych organ założycielski może dokonać samodzielnego powołania szefa placówki, nawet wbrew ocenom organizacji branżowych - zawodowych i twórczych. Tym samym może dojść do politycznego sterowania w płaszczyźnie kultury, gdzie ideowe uwarunkowania wygrają z argumentami artystycznymi. Faktycznie nie istnieje sprawny system zagwarantowania całkowitej niezależności twórcom oraz zabezpieczenie, że nie zostaną zastosowane środki skutkujące pozbawieniem ich stanowiska.

Głównym celem przygotowanego aktu prawnego było stworzenie ram dla funkcjonowania instytucji kultury w zmieniającym się świecie oraz dostosowanie zmian wobec wyzwań współczesności. Jednak są to rozwiązania nacechowane polityczną dominacją. Zakładana demokratyzacja, kluczowy element europeizacji, w kwestii organizacji życia teatralnego - powoływania dyrektorów, funkcjonowania instytucji nie spełnia teraz pokładanych nadziei, gdyż jest możliwe i często występuje wpływanie władz na tę sferę kultury.

\section{Obraz instytucjonalny i finansowanie teatrów w Polsce}

Zgodnie ze wskazaną Ustawa o organizowaniu i prowadzeniu działalności kulturalnej organizatorami aktywności teatralnej są podmioty państwowe, samorządowe oraz instytucje pozarządowe i prywatne. Według danych statystycznych ${ }^{18}$,

${ }_{17}$ Rozporzadzenie Ministra Kultury i Dziedzictwa Narodowego z dnia 26 lipca 2012 r. w sprawie samorzadowych instytucji kultury, w których wytonienie kandydata na stanowisko dyrektora następuje $w$ drodze konkursu, Dz.U. 2012 poz. 889. Lista jest bardzo bogata i znajduje się na niej łącznie 367 instytucji: 51 bibliotek, 50 domów i ośrodków kultury, 101 muzeów, 39 galerii, biur wystaw artystycznych oraz ośrodków i centrów kultury i sztuki, 27 filharmonii, orkiestr symfonicznych i kameralnych, 14 teatrów operowych i tańca, 8 teatrów muzycznych i operetkowych, 49 teatrów dramatycznych, 25 teatrów lalkowych i 3 inne instytucje - Europejskie Centrum Solidarności i zespoły pieśni i tańca („Mazowsze” i „Śląsk”).

${ }_{18}$ Wszelkie dane, chyba że wskazano inaczej, za: Główny Urząd Statystyczny, Urząd Statystyczny w Krakowie, Działalność instytucji kultury w Polsce w 2013 roku, oprac. Z. Bańka, 
dotyczących instytucji posiadających stały zespół artystyczny, zarówno w sektorze publicznym, jak i prywatnym ${ }^{19}$, w Polsce funkcjonują 72 teatry dramatyczne ${ }^{20}, 30$ teatrów lalkowych ${ }^{21}, 24$ teatry muzyczne ${ }^{22}$, w tym 11 oper i 13 operetek oraz 87 teatrów tańca i ruchu ${ }^{23}$. W konsekwencji przeprowadzonej decentralizacji państwa, której ostatni etap nastąpił z dniem 1 stycznia 1999 roku, większość instytucji kultury znalazła się w gestii podmiotów samorządowych oraz finansowana jest $\mathrm{z}$ ich dochodów własnych. Proces zmian charakteryzował się chaosem i brakiem logiki. Faktycznie przeprowadzana w wielkim pośpiechu przemiana organizacyjna skutkowała arbitralnym podporządkowaniem jednostkom samorządowym scen i innych instytucji kultury. Kryteriami podziału nie była ranga podmiotu, ale jej wielkość i charakter działalności - duże teatry i opery przypadły samorządowi wojewódzkiemu, a mniejsze sceny trafiły do miast i powiatów ${ }^{24}$.

Niewielki odsetek instytucji kultury pozostał w gestii i prowadzony jest przez ministra właściwego do spraw kultury i ochrony dziedzictwa narodowego. Spośród teatrów są to cztery podmioty: Teatr Narodowy w Warszawie, Narodowy Stary Teatr im. H. Modrzejewskiej w Krakowie, Teatr Wielki-Opera Narodowa (z Polskim Baletem Narodowym) w Warszawie i Polska Opera Królewska w Warszawie. Jako komplementarny wobec działalności praktycznej istnieje Instytut Teatralny im. Z. Raszewskiego w Warszawie. Jego główne zadania to organizowanie i koordynowanie promocji polskiego teatru w kraju i za granicą oraz ochrona zbiorów dokumentujących życie teatralne.

Do wskazanej powyżej grupy należy dołączyć instytucje współprowadzone przez ministra właściwego do spraw kultury i ochrony dziedzictwa narodowego, które są wpisane do rejestru podmiotów samorządowych. Faktycznie niweczy to założenia decentralizacji państwa, bowiem daje możliwość - przez wsparcie finansowe - wpływania przez organ władzy centralnej na konkretne instytucje i realizowane programy artystyczne. W tej grupie znajduje się 7 ośrodków teatralnych (Ośrodek Praktyk Teatralnych Gardzienice, teatry: im. S. Jaracza w Olsztynie, Polski im. A. Szyfmana

M. Kajzer, S. Kluza, D. Suder, file:///C:/Users/UW_D/Downloads/dzialalnosc_instytucji_kultury_w_ polsce_w_2013.pdf [odczyt: 15.08.2014].

${ }^{19} \mathrm{~W}$ ujęciu autora to rozróżnienie nie do końca właściwe. Faktycznie wszystkie podmioty działające w sektorze teatru mają charakter publiczny, bowiem korzystają w większości ze źródeł publicznego finansowania (np. w formie konkursów, dotacji) na szczeblu samorządowym i państwowym.

20 Jeżeli uwzględni się wszystkie instytucje teatralne, również działające bez stałego zespołu artystycznego, to będzie to liczba 91 podmiotów, za portalem e-teatr.pl, http://www.twp2015.e-teatr.pl/type/1 [odczyt: 15.08.2014].

${ }_{21}$ Trudno dokładnie określić, które teatry pracują tylko w technice lalek, lepsze byłoby określenie teatr dla dzieci, gdyż większość wykorzystuje również plan aktorski w wystawianych spektaklach. Gdy uwzględnimy wszystkie instytucje, również bez zespołu artystycznego, to okazuje się, że jest to 66 teatrów, http://www.twp2015.e-teatr.p1/type/3 [odczyt: 15.08.2014].

${ }^{22}$ Bez zespołu artystycznego to 33 instytucje artystyczne, http://www.twp2015.e-teatr.pl/type/2 [odczyt: 15.08.2014].

${ }^{23}$ Obliczenia własne na podstawie, http://www.twp2015.e-teatr.pl/type/4 [odczyt: 15.08.2014].

${ }^{24}$ P. Płoski, System teatralny w Polsce [w:] K. Prykowska-Michalak (red.), System organizacji teatrów w Europie, Warszawa 2016, s. 93-95. 
w Warszawie, Polski we Wrocławiu, Wierszalin w Supraślu, Wybrzeże w Gdańsku, Żydowski im. Estery Rachel i Idy Kamińskich - Centrum Kultury Jidysz w Warszawie) i 4 sceny muzyczne (Opera i Filharmonia Podlaska - Europejskie Centrum Sztuki w Białymstoku, Opera Nova w Bydgoszczy, Opera Wrocławska, Teatr Wielki im. S. Moniuszki w Poznaniu). Pojawienie się tej formy organizacyjnej związane jest z okresem sprawowania funkcji ministra kultury przez Waldemara Dąbrowskiego (2002-2005), który dążył, aby w każdym województwie znajdowała się choć jedna instytucja posiadająca znamiona współpracy szczebla centralnego z lokalnym. Miało to być wyrazem uhonorowania osiągnięć i dorobku kulturalnego bądź artystycznego danego podmiotu. Praktyka pokazała, że była to idealistyczna koncepcja i znalazły się na liście obiekty skrajnie różne co do rangi artystycznej i znaczenia kulturalnego dla regionu oraz całego kraju.

Wzorzec organizacyjny powoduje, że faktycznie głównym podmiotem wspierającym finansowo działalność teatralną pozostają organy prowadzące instytucje szczebla samorządowego i państwowego. Organizatorzy przeznaczają dla konkretnych scen dotacje podmiotowe, które pokrywają przeciętnie około $75 \%$ działalności. Dodatkowym elementem wsparcia są dotacje celowe lub wpływy z aktywności artystycznej. Nie dotyczy to tylko sprzedaży biletów, ale również działalności dodatkowej, a mianowicie: wyjazdów na festiwale, edukacji, najmu czy też udziału w konkursach dedykowanych sztuce współczesnej (Konkurs na Wystawienie Polskiej Sztuki Współczesnej) albo też dzieł dawnych (Klasyka Żywa). Sponsoring prywatny jawi się marginesowo, jest rzadkim przypadkiem wsparcia polskiej sceny. Brak faktycznej, jasnej i klarownej reformy w polskiej kulturze po roku 1989 spowodował jej stagnację organizacyjną. To odziedziczona po poprzedniej epoce forma niezmienna z innowacyjnym rozwiązaniem - tworzeniem instytucji kultury przez podmioty niepubliczne i osoby prywatne. Nadal standardem jest funkcjonowanie teatrów ze stałym zespołem aktorskim, wielokrotnie będącym większym niż możliwości eksploatacyjne sceny.

Zmiany w organizacji życia teatralnego miały doprowadzić do najważniejszego rezultatu decentralizacji - poszerzenia zasad demokratycznych w państwie. Zbliżenie instytucji kultury do obywateli miało przynieść wymierne korzyści - samodzielność organizacyjną scen przy zwiększających się nakładach na kulturę. Jednak owo założenie wydaje się utopią. W sporej części instytucje teatralne nie wyzwoliły się spod politycznej dominacji organów założycielskich. Brak głębokich rozwiązań strukturalnych, mimo przeprowadzonej reformy, spowodował zbudowanie autonomicznych, lokalnych polityk kulturalnych, w których instytucje artystyczne nie są niezależnymi podmiotami, lecz podległymi władzy organizacyjnie i finansowo jednostkami. Jedną z największych bolączek przemian polskiego życia kulturalnego pozostała jego rzeczywista zależność od władzy politycznej, wielokrotnie negującej wolność artystyczną i organizacyjną podmiotów artystycznych.

W polskim modelu teatralnym brakuje rozwiązań znanych choćby w Wielkiej Brytanii czy Czechach. Strukturalnie dobrym rozwiązaniem, pobudzającym aktywność środowiska, jest istnienie budynków teatralnych bez zespołu, które służyłyby licznym, niezależnym kompaniom teatralnym. Niewiele jest zespołów funkcjonujących 
tylko w objeździe, podróżujących z konkretną produkcją teatralną, ale o wysokiej jakości artystycznej. Brakuje w naszym kraju rozwiązań finansowania znanych choćby w Wielkiej Brytanii i funkcjonujących rad sztuki złożonych z ekspertów i specjalistów, co faktycznie uwalnia przekazywanie funduszy od władz rządowych i lokalnych $^{25}$. Wówczas decentralizacja posiada wymierne skutki - uniezależnienie i potencjalnie właściwą, zgodną z potrzebami wspólnoty, dystrybucję pieniądza. Wskazując na doświadczenia naszych południowych sąsiadów, należy stwierdzić, że następstwo zmian wprowadzonych po roku 1989 doprowadziło do rozbicia hegemonii państwa w prowadzeniu instytucji kultury na wieloelementowy zbiór podmiotów zaangażowanych w kształtowanie czeskiej sceny. Na łączną liczbę 152 teatrów (stan na rok 2014) mniej niż jedna trzecia zarządzanych jest przez państwo, województwo, miasta i gminy ${ }^{26}$. Wskazana ogólna wartość placówek bliska jest polskiej mapie teatralnej, jednak w naszym kraju mamy blisko czterokrotnie więcej mieszkańców. Świadczy to o zupełnie odmiennym stosunku obywateli i zarządzających kulturą do tej sfery życia społecznego.

Obraz instytucjonalny i uczestnictwa w polskim życiu teatralnym charakteryzuje się dynamiką i zmianą. Dla przykładu w roku $2013^{27}$ działalność sceniczną prowadziło 170 placówek (teatry dramatyczne, lalkowe, muzyczne, filharmonie, orkiestry, chóry, zespoły pieśni i tańca) posiadających stały zespół artystyczny. To wynik gorszy niż w roku 2012, gdyż zanotowano spadek o cztery podmioty. Najwięcej instytucji zlokalizowanych było w województwie mazowieckim - aż 32, w małopolskim i śląskim po 18 , wobec $3 \mathrm{w}$ opolskim i podkarpackim. Instytucje artystyczne dysponowały 322 scenami stałymi (co daje przeciętnie 1,9 sceny w każdej placówce) i 81,9 tys. miejsc na widowniach. We wskazanym roku wystawiono 55,4 tys. przedstawień i koncertów, co daje średnio 326 pokazów na jedną instytucję. Jest to wzrost w stosunku do roku 2012 o 15 wydarzeń. Średnia liczba spektakli w teatrach dramatycznych i lalkowych wyniosła 306, a teatry muzyczne (opery i operetki) zaprezentowały przeciętnie 187 przedstawień. We wskazanych przypadkach odnotowano zwyżkę względem roku poprzedniego o kilkanaście prezentacji. Warto zwrócić uwagę,

${ }_{25}$ O modelu teatrów w Wielkiej Brytanii zob. J. Sławińska-Ryszka, Organizacja teatrów w Wielkiej Brytanii [w:] System organizacji teatrów..., s. 51-63; W.J. Karna, Wybrane zagadnienia zatrudnienia i wynagradzania w teatrach brytyjskich [w:] S. Flejterski, E. Roszkowska (red.), Teatry $w$ Europie. II międzynarodowa konferencja: teatr - otoczenie spoleczne, prawne i finansowe, Szczecin 2004, s. 41-48; M. Szum, Zarys struktury organizacyjnej teatrów Wielkiej Brytaniiwybrane aspekty ich finansowania i funkcjonowania [w:] K. Mazurek-Łopacińska (red.), Kultura polska a Unia Europejska. Problemy, wyzwania, nadzieje, Warszawa-Wrocław 1998, s. 71-91.

${ }^{26}$ Szerzej: S. Czachór, Czeski system teatralny [w:] System organizacji teatrów..., s. 223-250. O innych modelach polityk kulturalnych zob. D. Przastek, Polityka kulturalna w Polsce (i na świecie), „Studia BAS” $2016 \mathrm{nr}$ 2; Europejskie modele polityki kulturalnej, t. 1 i 2, red. B. Gierat-Bieroń (t. 1 i 2), K. Kowalski (t. 1), Kraków 2005-2006.

${ }^{27}$ Na podstawie: Główny Urząd Statystyczny, Urząd Statystyczny w Krakowie, Działalność instytucji kultury w Polsce w 2013 roku... i Główny Urząd Statystyczny, Urząd Statystyczny w Krakowie, Działalność instytucji kultury w Polsce w 2012, oprac. E. Bińczycka, M. Czwartkowska, B. Jędrychowska, S. Kluza, M. Plata, http://stat.gov.pl/cps/rde/xbcr/gus/KTS_dzialalnosc_instyt_ kultury_w_polsce_2012.pdf [odczyt: 18.08.2014]. 
że zwiększyła się również - i to znacząco - liczba premier w teatrach. Wyniosła ona 715 wobec 609 w roku 2012, czyli wzrosła o 17,4\%. Liderem jest województwo mazowieckie, gdzie odbyło się $21,8 \%$ ogółu nowych prezentacji w 21 teatrach. Najwięcej pokazów scenicznych zaprezentowano w województwie mazowieckim - 12,994 tys., a najmniej w lubelskim - 915. Uczestniczyło w nich 11,5 mln widzów i słuchaczy. Największa i najmniejsza liczba odbiorców jest analogiczna do liczby instytucji artystycznych w poszczególnych województwach. Przeciętnie jeden pokaz oglądało 198 widzów w siedzibie i aż 306 poza stałym miejscem prezentacji, choć gościnne pokazy stanowią $8 \%$ całej działalności.

Dodatkową formą aktywności scen jest animacja edukacyjna. Przygotowano 13,4 tys. odczytów i prelekcji, seansów filmowych, koncertów, konkursów, festiwali, imprez plenerowych, sesji i seminariów naukowych. Wydarzenia te zgromadziły 2,7 mln uczestników - o 12,9\% więcej niż rok wcześniej - co świadczy o ich deficycie i dużym zainteresowaniu tą formą działalności u widzów. Można zauważyć, że placówki sceniczne coraz częściej przybierają formę artystycznych domów kultury, co zbliża je do brytyjskiego modelu organizacji teatrów (playhouse). Szczególnie jest to zauważalne w mniejszych ośrodkach. Teatr staje się miejscem spotkania kultury i nie ogranicza się tylko do wieczornej prezentacji spektakli dla wąskiego grona widzów. Jest otwarty przez cały dzień dla wszystkich potencjalnych odbiorców. Coraz bardziej popularne są warsztaty dla uczniów szkół, prelekcje i pokazy filmów. Prawie każdy duży ośrodek teatralny w Polsce posiada własny festiwal. W celu otwarcia teatrów dla nowej publiczności zakłada się kawiarnie teatralne, które służą organizacji wieczorów literackich i miejsc spotkań z twórcami.

Przedstawione wyniki badań, mimo wzrostu uczestniczących w spektaklach i koncertach artystycznych, nie nastrajają optymizmem. Przeciętnie sale widowiskowe odwiedziło 207 osób, co nie zapełnia widowni większości placówek. Istnieją bardzo duże dysproporcje uczestnictwa w wydarzeniach teatralnych i koncertach pomiędzy ośrodkami lokalnymi. Jest pewna prawidłowość większej widowni na koncertach filharmonicznych, operze i musicalach niż w teatrach dramatycznych. Druga bolączka to fakt, że ponad 2/3 Polaków nie uczestniczy w wydarzeniach kulturalnych zarówno na scenach teatralnych, jak i w salach koncertowych. Dla porównania w Czechach w życiu teatralnym bierze czynny udział ponad połowa obywateli. Teatr i muzyka poważna traktowane są jako dziedziny elitarne, które część społeczeństwa omija szerokim łukiem jako niedostępne i zbyt trudne w odbiorze. Należy stwierdzić, że jest to konsekwencją systemu edukacyjnego i braku wystarczającej wiedzy o zjawiskach artystycznych. Zapewne stąd rodzi się dodatkowa aktywność scen w celu pozyskania nowych odbiorców i chęć ich zaangażowania w kulturę. Przeciętny Polak od teatru oczekuje rozrywki, relaksu i nowych perspektyw kulturowych. Widz najczęściej wybiera spektakl ze względu na znanych aktorów ${ }^{28}$. I chyba owa perspektywa jest spójna z doświadczeniami całej Europy.

Ostatnie lata spowodowały nie tylko zauważalne zmiany w wewnętrznej organizacji poszczególnych scen, lecz także stworzyły komplementarne formy wsparcia

${ }^{28}$ Za: Badanie publiczności teatrów stolicy. Raport, Warszawa 2013. 
finansowego szeroko rozumianych działań teatralnych. Wiążą się one bezpośrednio z udziałem Polski w strukturach europejskich oraz stworzoną płaszczyzną subwencji z budżetu centralnego.

Wsparcie finansowe Unii Europejskiej było i jest możliwe w dwojaki sposób. Po pierwsze, przez mechanizm dedykowanych sferze kultury programów, w których Polska już uczestniczyła jako państwo stowarzyszone przed przystąpieniem do Unii Europejskiej - Kultura 2000 (realizowany do roku 2006), Kultura 2007-2013 oraz Kreatywna Europa z jednym z trzech elementów - Kultura. Przy uwzględnieniu celów programów nadrzędne było budowanie europejskiej wspólnoty przez działania artystyczne i kulturowe polegające na: zwiększeniu mobilności osób działających w sektorze kultury; obiegu dzieł i wyrobów artystycznych i kulturowych oraz zintensyfikowaniu dialogu międzykulturowego. Tym samym stanowi to praktyczny wymiar europeizacji - element procesów integracyjnych, uwspólnotowienia kultury.

Analiza uczestnictwa polskiej sceny w programach nie ukazuje szerokiego udziału i partycypacji. Dane dotyczące beneficjentów w zakresie sztuk performatywnych w przedziałach jednorocznych, gdzie polski podmiot był liderem, wskazują w sferze teatru w latach 2000-2006 zaledwie dziewięć projektów. Były to m.in.: dwukrotnie Wrocławski Teatr Współczesny - Międzynarodowy Festiwal Teatralny „,Dialog” w latach 2001 i 2005; trzykrotnie Fundacja Theatrum Gedanense - w różny sposób wsparcie Festiwalu Szekspirowskiego w latach 2003, 2005 i 2006; Państwowa Wyższa Szkoła Filmowa, Telewizyjna i Teatralna im. L. Schillera w Łodzi - European Neighbours - European Theatre (2003) ${ }^{29}$. W latach 2007-2013 koordynatorem polski podmiot był pięciokrotnie, a jako uczestnik - dziewiętnaście razy. Realizowane projekty jako lider w dziedzinie teatru to: Teatr Nowy im. T. Łomnickiego w Poznaniu - Arka Noego. Nowy Koniec Europy (2008) z udziałem partnerów teatralnych z Włoch, Izraela, Austrii, Niemiec i Kosowa; Teatr Baj Pomorski w Toruniu - Latający Festiwal - Rodzina i Dziecko we wspótczesnej Europie (2009) oraz trzykrotnie - Fundacja Theatrum Gedanense - wsparcie Festiwalu Szekspirowskiego w latach 2009, 2010 i $2012^{30}$. Przyczyn owej niewielkiej aktywności należy poszukiwać w założeniach i wymogach regulaminowych. Głównym problemem staje się poszukiwanie partnerów zagranicznych do realizacji zadania. Drugi aspekt to faktycznie sztuczne tworzenie, pod zasady programów, repertuaru imprez, co może skutkować obniżeniem jego wartości artystycznej. Kreatywna Europa jest obecnie w fazie realizacji. Trudno dokonywać podsumowań, ale można dla przykładu wskazać jeden projekt współtworzony przez polski podmiot. Fabulamundi. Playwriting Europe. Beyond Borders ${ }^{31}$ - to przedsięwzięcie rozpisane na lata 2017-2020 zakładające rozwój i promocję współczesnej dramaturgii poprzez tłumaczenia sztuk, prezentacje współczesnych dramatów, warsztaty dla dramatopisarzy czy też stworzenie europejskiej

${ }^{29} \mathrm{Za}$ : www.ec.europa.eu/programmes/creative-europe/previous-programmes/culture-2000_en [odczyt: 25.07.2017].

${ }^{30}$ Program Kultura 2007-2013 w Polsce. Analiza i podsumowanie, A. Hieropolitańska, K. Rola (red.), Warszawa 2013.

31 Zob. www.fabulamundi.eu [odczyt: 25.07.2017]. 
sieci dla twórców tekstów scenicznych. W projekcie uczestniczy 10 państw. Liderem jest włoska organizacja PAV, specjalizująca się w opracowywaniu i wdrażaniu projektów kulturalnych. Z Polski udział bierze warszawski Teatr Dramatyczny, kierowany przez dramatopisarza Tadeusza Słobodzianka.

Przystąpienie Polski do Unii Europejskiej stworzyło możliwość pełnego pozyskiwania środków z funduszy strukturalnych. To drugie pole wsparcia polskiego sektora teatralnego - infrastruktury i wyposażenia scen. W tym zakresie kluczowe stało się przygotowanie i przyjęcie przez Radę Ministrów 21 września 2004 roku Narodowej Strategii Rozwoju Kultury 2004-2013 oraz Uzupetnienie Narodowej Strategii Rozwoju Kultury na lata 2004-202032. To jeden z najważniejszych aktów ostatnich dwudziestu pięciu lat $\mathrm{w}$ dziedzinie kultury. Ten sektor został wpisany w możliwe unijne wsparcie w ramach programów operacyjnych rozwoju regionalnego. Służą one wzrostowi poziomu społeczno-ekonomicznej spójności wszystkich regionów Unii. Co więcej, wpływają na rozwój konkurencyjności i podnoszenie jakości życia mieszkańców ${ }^{33}$.

Założenia Narodowej Strategii Rozwoju Kultury lokowały państwo jako kreatora polityki horyzontalnej i ,sektorowej” w sferze kultury poprzez działania ministra kultury i jednostki samorządu terytorialnego. Realizacja strategii koncentrowała się na działaniach w województwach (samorząd wojewódzki), gdyż tam wydawane są pieniądze. Do 15 maja 2005 roku zarządy województw w ramach Zintegrowanego Programu Operacyjnego Rozwoju Regionalnego (wykorzystującego środki Europejskiego Funduszu Rozwoju Regionalnego i Europejskiego Funduszu Społecznego) wybrały do realizacji 112 projektów z zakresu kultury ${ }^{34}$. Podsumowanie lat 20042006 zamykało się wybranymi do realizacji 298 projektami z zakresu kultury o całkowitej wartości $386 \mathrm{mln}$ euro ${ }^{35}$. Kolejne lata wskazują na dalszą dużą aktywność w tym zakresie. W latach 2007-2013 lącznie w sektorze kultury z Europejskiego Funduszu Rozwoju Regionalnego wydatkowano 4,8 mld zł, w ramach XI priorytetu Kultura i dziedzictwo kulturowe Programu Operacyjnego Infrastruktura i Środowisko 20072013 dofinansowanie otrzymało 79 projektów o wartości przekraczającej 4 mld zł, $\mathrm{z}$ czego środki europejskie to $2,3 \mathrm{mld} \mathrm{z}^{36}$. Wsparciem unijnym objęto m.in.: budowę od podstaw - niebędącą dostosowaniem innego budynku - pierwszego od czterdziestu lat obiektu teatralnego w Polsce - Teatru Szekspirowskiego w Gdańsku; przebudowę Teatru Muzycznego Capitol we Wrocławiu; rewitalizację Teatru im. S. Jara-

${ }^{32}$ Narodowa Strategia Rozwoju Kultury na lata 2004-2013, Ministerstwo Kultury, http://bip. mkidn.gov.pl/media/docs/Narodowa_Strategia_Rozwoju_Kultury.pdf [odczyt: 22.07.2015] oraz Uzupetnienie Narodowej Strategii Rozwoju Kultury na lata 2004-2020, Ministerstwo Kultury, http:// bip.mkidn.gov.pl/media/docs/050617nsrk-uzupelnienie.pdf [odczyt: 22.07.2015].

${ }^{33}$ Szerzej o roli funduszy europejskich dla kultury zob. M. Smoleń, Nowa perspektywa finansowa 2007-2013 - perspektywy dla kultury, „Zarządzanie Publiczne” 2005, nr 1, s. 127-137.

34 W. Dąbrowski, Wielki czas budowania, rozmawiali K. Długosz i J. Domański, „Przegląd” 2005, nr 29, s. 14.

${ }_{35}$ Mecenat petnowymiarowy. Polityka kulturalna państwa 2005-2007, Warszawa 2007, s. 19.

${ }^{36}$ Ministerstwo Kultury i Dziedzictwa Narodowego, Działania MKiDN w latach 2007-2015, Warszawa 2015. Broszura w zbiorach autora. W ramach Programu Operacyjnego Infrastruktura i Środowisko na lata 2014-2020 alokacja wynosi około 2 mld zł z przeznaczeniem na rewitalizację zabytków i poprawę jakości funkcjonowania instytucji kultury. 
cza w Olsztynie; renowację Teatru Starego w Lublinie; rekonstrukcję i przebudowę Teatru im. S.I. Witkiewicza w Zakopanem, budowy: Europejskiego Ośrodka Praktyk Teatralnych w Gardzienicach i Międzynarodowego Centrum Kultury Nowy Teatr w Warszawie. Dofinansowanie wahało się od 50 do 80 procent wartości inwestycji. Ów mechanizm zwiększa atrakcyjność obiektów kultury, zbliża je do standardów starej Unii i tworzy atrakcyjne ośrodki kulturowe dla szerokiej grupy odbiorców.

Najczęstszą formą wsparcia finansowego szczebla centralnego dla działań teatralnych - jednostek samorządowych i niezależnych podmiotów (organizacje pozarządowe, Kościoły i związki wyznaniowe, podmioty prowadzące działalność gospodarczą) - pozostają jednak programy operacyjne ministra. Wynikały one ze wspomnianego Uzupetnienia Strategii i stanowiły jej narzędzie realizacyjne. W chwili obecnej najbardziej znaczący dla dziedziny teatru jest Program z zakresu twórczości artystycznej i edukacji kulturalnej - Teatr i taniec, którego strategicznym cel stanowi wspieranie najwartościowszych zjawisk oraz trendów w teatrze i tańcu. Budżet jego w 2017 roku wynosił 11,5 mln $\mathrm{zf}^{37}$.

System programów ministra, których obecnie jest 34, został stworzony dla wspierania inicjatyw kulturalnych niepolegających na bezpośrednim dotowaniu przez ministra właściwego do spraw kultury i ochrony dziedzictwa narodowego, ale w formie konkursu ${ }^{38}$. Wzorowany na brytyjskim modelu ,przedłużonego ramienia” uniezależnia, w teorii, przyznawanie wsparcia. Samodzielne zespoły sterujące, powoływane przez ministra, dokonują oceny wniosków, które otrzymują dofinansowanie. Jednak procedura odwoławcza pozostawiła możliwość samodzielnej decyzji ministra co do przekazania środków dla wybranego przez niego przedsięwzięcia, niezależnie od miejsca w rankingu wskazanego przez komisję oceniającą.

Polski model życia teatralnego charakteryzuje się decentralizacją, co jest zgodne ze wzorcami i trendami europejskimi. Jednak praktyka wskazuje, że jest on poddany silnym wpływom politycznym zarówno szczebla centralnego, jak i lokalnego. Niezależność organizacyjna czy też mechanizm dystrybucji wewnętrznych funduszy znany z rozwiązań brytyjskich nie ma odzwierciedlenia na gruncie polskim. To jeden z ważnych wyznaczników i koniecznych zmian dla wolnej polskiej kultury w demokratycznej Europie.

\section{Aktywność Polski w europejskich inicjatywach teatralnych}

Europejskie życie kulturalne charakteryzuje się różnorodnymi, spontanicznymi inicjatywami, które unifikują i aktywizują twórców oraz artystów. To również wspólnoty instytucjonalne - organizacje powoływane do realizacji konkretnych

37 Za: www.mkidn.gov.pl [odczyt: 27.07.2017]. Należy wspomnieć o innych programach, np. poprawiających wyposażenie scen - choćby Infrastruktura kultury.

${ }^{38}$ Dopełnienie stanowi Rozporzadzenie Ministra Kultury z dnia 1 września 2005 r. w sprawie zakresu zadań objętych mecenatem państwa, szczegółowego trybu składania wniosków o udzielenie dotacji oraz trybu przekazywania i rozliczania udzielonych dotacji, Dz.U. nr 177 poz. 1474. 
przedsięwzięć i zadań w danych dziedzinach sztuki. Współpraca europejska w sferze teatru doczekała się kilku tego typu inicjatyw. Jednak polski udział w tychże przedsięwzięciach jest raczej znikomy, a faktycznie marginalny.

Do najważniejszych tego typu podmiotów należy Unia Teatrów Europy (UTE Union des Theatres de l'Europe). Utworzone z inicjatywy włoskiego reżysera Giorgio Strehlera w marcu 1990 roku stowarzyszenie (funkcjonujące na mocy prawa francuskiego) działa na rzecz budowania Unii Europejskiej przez kulturę i teatr oraz rozwijania wspólnej działalności kulturalnej z przekraczaniem granic językowych. Kluczowymi aspektami działalności - miejscami spotkań i wymiany poglądów - stały się warsztaty dedykowane konkretnym grupom twórców oraz festiwal teatralny. Realizowany od roku 1992, jest przeglądem najciekawszych przedstawień teatrów skupionych w organizacji. W 1996 roku odbywał się w Krakowie ${ }^{39}$. Ostatnie edycje miały charakter tematyczny i poświęcone były problemom współczesności, np. tolerancji (St. Petersburg 2014) czy terroryzmowi (Stuttgart 2015) ${ }^{40}$.

Dziś organizacja skupia dwadzieścia zespołów teatralnych z różnych państw europejskich oraz Izraela, nie ma wśród nich polskiej instytucji kultury. Przez lata aktywnym członkiem był Stary Teatr im. H. Modrzejewskiej w Krakowie, czego wymiernym rezultatem było powierzenie organizacji wspomnianego festiwalu. Drugą grupę uczestników stanowią osoby indywidualne. W gronie międzynarodowych indywidualności kultury i sceny europejskiej obecnie znajdują się dwie osoby z Polski: jako członek honorowy - Krystian Lupa, najwybitniejszy polski reżyser teatralny, oraz będący członkiem indywidulanym - Tadeusz Bradecki, aktor, reżyser i dyrektor Starego Teatru w Krakowie w latach 1990-1996. Do owej grupy jako członek honorowy, aż do śmierci w roku 2016, należał reżyser filmowy i teatralny Andrzej Wajda.

Unia Teatrów Europy jest główną organizacją partnerską dla najważniejszego wydarzenia w dziedzinie teatru w Europie - Europejskiej Nagrody Teatralnej (Premio Europa per il Teatro). Została ona powołana w latach 1986-1987 przez Komisję Europejską jako pilotażowy program w dziedzinie teatru. Parlament Europejski i Rada Europy uznają ją za wydarzenie tworzące europejską wartość kulturową. Za główne cele uznaje się promowanie dramatu i wiedzy o dramacie w Europie, sprzyjanie rozwojowi kontaktów kulturalnych i wzbogacanie europejskiej zbiorowej świadomości ${ }^{41}$. Przewodniczącym lauru jest Jack Lang, były minister kultury Francji, faktyczny ojciec obecności kultury we współpracy europejskiej. Od roku 1987 przyznawana jest Europejska Nagroda Teatralna, która trafia do artystów lub zespołów przyczyniających się do powstania wydarzeń kulturalnych promujących zrozumienie i wymianę wiedzy pomiędzy narodami. Od trzeciej edycji (1990) wręczana jest Europejska Nagroda „Nowe Rzeczywistości Teatralne”, której cel stanowi wspieranie nowych trendów i inicjatyw w europejskim teatrze. Polskie konotacje są dwojakiego

39 O owej aktywności pisał D. Przastek, Europejska wspótpraca kulturalna. Unia Teatrów Europy, „Przegląd Europejski” 2002, nr 2, s. 145-165.

${ }^{40} \mathrm{O}$ obecnej działalności Unii Teatrów Europy zobacz, http://www.union-theatres-europe.eu [odczyt: 25.07.2017].

${ }^{41} \mathrm{Za}$ : Europejska Nagroda Teatralna. Regulamin Nagrody [w:] M. Giovanelli (red.), katalog 13 Europejska Nagroda Teatralna, Wrocław 2009, s. 35. 
rodzaju. Pierwsze, związane z organizacją wydarzenia (Wrocław w 2009 roku), i drugie - z laureatami. W roku 2008 podczas X edycji Europejskiej Nagrody „Nowe Rzeczywistości Teatralne" odebrał ją reżyser, dziś dyrektor artystyczny Nowego Teatru w Warszawie - Krzysztof Warlikowski. Polskim laureatem Europejskiej Nagrody Teatralnej został w 2009 roku wspomniany już Krystian Lupa. To szczególne uhonorowanie dla indywidualności, znaczenia i stylistycznego wyrazu polskiej sceny. Dla dopełnienia jej znaczenia warto zwrócić uwagę na listę nominowanych od pierwszej do trzynastej edycji nagrody „Nowych Rzeczywistości Teatralnych”. Znajdują się na niej cztery osoby i instytucje z Polski, a mianowicie: reżyser i dyrektor artystyczny TR Warszawa - Grzegorz Jarzyna, reżyser Paweł Szkotak z Teatrem Biuro Podróży, wrocławski Teatr Pieśń Kozła prowadzony przez Grzegorza Brala oraz reżyser i dyrektor Narodowego Starego Teatru im. H. Modrzejewskiej w Krakowie w latach 2013-2016 - Jan Klata ${ }^{42}$. Wydarzenie jest jednym z najważniejszych elementów pobudzania świadomości europejskiej w dziedzinie teatru - ukazywania różnorodności budującej tożsamość artystyczną kontynentu.

Zbliżonymi formami do aktywności Unii Teatrów Europy pozostaje działalność Europejskiej Konwencji Teatralnej (European Theatre Convention) oraz Mitos 21 Europejskiej Sieci Teatrów (European Theatre Network).

Pierwsza z nich powstała w roku 1988 i skupia europejskie teatry publiczne. Jako główne cele wyznacza sobie: promocję współczesnego dramatu europejskiego, wsparcie mobilności artystów oraz wymianę teatralną zarówno na kontynencie, jak i poza jego granicami. Konwencja skupia 40 teatrów w 23 krajach. Aktywność służy zbliżeniu twórców teatralnych z obywatelami oraz wspieraniu dialogu międzykulturowego. Najlepszym przykładem może być obecnie realizowany projekt Teatr $w$ DialoguDialog Kultur: Europejska sieć z teatrami wschodnioeuropejskimi. Uczestniczą w nim zespoły z Niemiec, Ukrainy, Gruzji i Mołdawii. To cykl warsztatów, spotkań, stypendiów, rezydencji dla twórców tych państw, służący poznaniu i wymianie doświadczeń artystycznych ${ }^{43}$. Jednym z najciekawszych zrealizowanych projektów była inicjatywa z roku 2009 o nazwie Orient Express - europejska podróż i festiwal teatralny. W ciągu dwóch miesięcy (od maja do lipca) specjalny pociąg przemierzał 11 miast w 6 państwach. Od Ankary do Stuttgartu, zatrzymując się na stacjach kolejowych, w specjalnie przystosowanym wagonie, teatry - członkowie organizacji prezentowały spektakle powiązane z tematyką podróży. Finałem stał się dworzec w Stuttgarcie, gdzie wszystkie zespoły podczas dwutygodniowego spotkania zaprezentowały swoje przedstawienia $^{44}$. W Europejskiej Konwencji Teatralnej obecnie nie ma ani jednego przedstawiciela Polski. Przez kilka lat członkiem był poznański Teatr Nowy im. T. Łomnickiego. Jednak wycofał się z owej współpracy. Odstraszająca może być konieczność wpłaty 5500 euro dla uczestnictwa pełnego i 2500 euro dla stowarzyszonego.

Nazwa drugiego podmiotu - Mitos - związana jest ze słowem starożytnym, które oznacza „nić”. To nawiązanie do mitu o nici Ariadny, która pomogła wyjść

42 Za: katalog 15th Europe Theatre Prize, L. Mususmarra (red.), Craiova 2016, s. 151-152.

${ }^{43}$ Szerzej, http://www.etc-cte.org [odczyt: 25.07.2017].

$44 \mathrm{Za}$ : Invitation to the press conference May 14 2009, w zbiorach autora. 
Tezeuszowi z labiryntu. Analogicznie Mitos 21 realizuje ideę poszukiwania różnego spojrzenia na teatr poprzez jego rolę społeczną oraz stworzenie możliwości spotkania i współpracy artystów z różnych państw europejskich. Powstałe w październiku 2008 roku stowarzyszenie skupia twórców teatralnych z najważniejszych teatrów europejskich. Główną ideą - początkowo przez nieformalne spotkania, bez instytucjonalnej struktury, ale dzięki realizacji konkretnych projektów, których koordynatorem był jeden ze stowarzyszonych teatrów - stała się realna współpraca oraz rozwijanie i ukazywanie aktywności teatru we współczesnym społeczeństwie. Od roku 2012 Mitos 21 posiada swoją siedzibę, która wyznaczana jest na zasadzie rotacji pomiędzy poszczególne teatry wchodzące w skład sieci (w latach 2017-2018 to The National Theatre w Londynie). Obecnie liczy ona 15 członków instytucjonalnych - wśród nich jest Narodowy Stary Teatr im. Heleny Modrzejewskiej w Krakowie, oraz 6 członków indywidualnych - jednym z nich jest reżyser i pedagog Mikołaj Grabowski ${ }^{45}$. Najciekawsze wspólne projekty organizacji to m.in.: zorganizowany w dniach 4-6 czerwca 2009 roku w Sztokholmie w ramach Festiwalu Ingmara Bergmana Obama Victory Speech Project, będący prezentacją monodramów przygotowanych przez artystów $\mathrm{z}$ teatrów skupionych $\mathrm{w}$ stowarzyszeniu. Punktem wyjścia stało się wystąpienie nowo wybranego Prezydenta Stanów Zjednoczonych Baracka Obamy. Wydarzenie ukazało możliwe interpretacje mowy politycznej i lokowało teatr jak najbliżej życia codziennego. W 2012 roku wydano publikację Mitos 21. Antologia (tom I i II) ${ }^{46}$. Pozycja zawiera pięć dramatów w języku polskim oraz cztery te same w językach oryginalnych - węgierskim, duńskim i niemieckim ${ }^{47}$. Sztuki zostały dobrane według rekomendacji dramaturgów bądź kierowników literackich działających w sieci. To teksty, które dotykają problematyki współczesnych społeczeństw - bolączek, rozterek i nieuniknionych katastrof. Dzisiejsza aktywność to różnego rodzaju spotkania, warsztaty i konferencje, których celem jest realizacja założeń programowych sieci.

Ostatnią formą współpracy instytucjonalnej - choć nie bezpośrednio w sferze teatru, ale dedykowana operze - jest Opera Europa, której tradycja sięga roku 1995. To najważniejsza na kontynencie europejskim organizacja kulturalna, podlegająca prawu belgijskiemu, dedykowana teatrom i festiwalom operowym. Siedzibą jest Bruksela. Skupia obecnie 176 podmiotów z 42 państw, które zobligowane są do opłacenia corocznej składki członkowskiej w wysokości 2700 euro. Z naszego kraju to aż sześć podmiotów: Teatr Wielki-Opera Narodowa w Warszawie, Opera Bałtycka w Gdańsku, Capella Cracoviensis w Krakowie, Teatr Wielki w Poznaniu, Opera Wrocławska i Polska Orkiestra Sinfonia Iuventus. W zarządzie znajduje się przedstawicielka Polski Renata Borowska-Juszczyńska, dyrektor naczelny Teatru Wielkiego im. S. Moniuszki w Poznaniu ${ }^{48}$. Najważniejsze praktyczne wydarzenia realizują nadrzędny cel podmiotu - przybliżanie sztuki operowej mieszkańcom Europy. Służy temu

${ }^{45} \mathrm{http}: / /$ mitos21.com/ i http://stary.pl/pl/mitos21/ [odczyt: 25.07.2017].

${ }^{46}$ Mitos 21. Antologia, t. I i II, A. Fryz-Więcek, S. Wróblewski (red.), Kraków 2012.

47 Agencja Bloomsbury Publishing Plc nie wyraziła zgody na druk oryginalnej wersji dramatu brytyjskiego Trzesienie ziemi w Londynie.

${ }^{48}$ Szerzej, http://www.opera-europa.org. [odczyt: 25.07.2017]. 
aktywność strony internetowej The Opera Platform (www.theoperaplatform.eu), która udostępnia rejestracje spektakli teatrów-członków organizacji. Obecnie korzysta $\mathrm{z}$ niej ponad dwa miliony użytkowników sieci. Bez wychodzenia z domu każdy Europejczyk może zapoznać się z kanonem muzyki, a także sięgnąć do źródeł europejskiej sztuki wokalnej bądź współczesnych osiągnięć kompozytorskich. Jak dotychczas, w ramach owej aktywności prezentowano dwie polskie produkcje: Goplanę Władysława Żeleńskiego w reżyserii Janusza Wiśniewskiego z Teatru Wielkiego-Opery Narodowej w Warszawie i Space Operę Aleksandra Nowaka w reżyserii Eweliny Pietrowiak z Teatru Wielkiego im. S. Moniuszki w Poznaniu. Drugą znaczącą formą zaznajomienia szerokiego grona uczestników kultury z tą dziedziną sztuki są Europejskie Dni Opery. W roku 2017 zorganizowane pomiędzy 5 a 14 maja stały się szansą przybliżenia opery poprzez aktywność w sieci klasyczne spektakle oraz niekonwencjonalne pikniki w przestrzeni publicznej. To jedno z najważniejszych pól aktywności ukazuje, że kultura może być blisko obywatela, a opera uważana za elitarną staje się bliska i dostępna dla szerokiego odbiorcy. Klasycznymi formami aktywności Opera Europe pozostają spotkania, konferencje i sympozja służące wymianie doświadczeń w zarządzaniu współczesnym teatrem operowym.

Wskazane formy aktywności wyznaczają pola zbliżania się instytucji teatralnych Europy. To możliwy szeroki wachlarz współpracy, ale budowany nie odgórnym państwowym narzuceniem, lecz spontaniczną potrzebą kooperacji. W płaszczyźnie współpracy międzynarodowej unaocznia się europeizacja w dziedzinie teatru, która służy konkretnym wymiernym celom. Skatalogować je można w czterech segmentach. Są to: 1) Poszerzenie oferty kulturalnej dla widzów, odbiorców i uczestników poprzez odmienne zjawiska artystyczne. 2) Poznanie i implementacja różnorodnych modeli zarządzania instytucjami artystycznymi. 3) Zdobywanie doświadczeń przez twórców oraz artystów. 4) Budowanie środowiska teatru europejskiego.

Jak wynika z powyższej analizy, polska działalność na tle innych państw kontynentu jawi się dziś marginesowo i sporadycznie. Należy podkreślić, że w końcu lat dziewięćdziesiątych XX wieku Stary Teatr w Krakowie był liderem aktywności w Unii Teatrów Europy. Nie doszukując się głębszych przyczyn zmiany i braku zaangażowania, należy jako pozytyw wskazać aktywność instytucji operowych. Może to stanowić zaczyn dla potencjalnego wzrostu zainteresowania teatrów dramatycznych tą formą działania, która przyczynia się do podnoszenia poziomu świadomości i wspólnotowości Europy.

\section{Charakter i znaczenie polskiej sceny w Europie}

Cechą wyróżniającą polski teatr jest jej polityczny charakter ${ }^{49}$. Wykazać to można w dwojaki sposób. Z jednej strony jako formy zaangażowanej, z drugiej - odżegnującej się od wspierania określonych idei czy wartości. Owa cecha definiowana

49 Teatr polityczny należy traktować bardzo szeroko jako teatr pozostający w bezpośredniej bądź pośredniej relacji do reżimu politycznego danego państwa. Odwzorowane jest to w praktyce 
była niedemokratycznym reżimem politycznym, który wymuszał na sztuce podległość i uznanie, ale również poszukiwanie pól niezależności ${ }^{50}$. Paweł Mościcki w eseju Teatr angażujacy zauważył, że współczesny teatr polityczny powinien zajmować się najróżniejszymi formami, symbolami, dyskursami, za pomocą których społeczeństwo chce sobie siebie przedstawićs ${ }^{51}$. Teatr ostatnich dwudziestu pięciu lat jest ważnym obserwatorem rzeczywistości. Jest polemiczny, dygresyjny, komentujący. Wzbudza emocje, spektakle swoją formą i poruszaną problematyką otwierają dotychczas nieznane pokłady wrażliwości artystycznej. Jego główną cechą wyróżniającą pozostaje aktualność. Mimo przedstawionego jasno określonego charakteru polskiego teatru, który odpowiadałby ujęciu sztuki krytycznej, nie posiada on wykrystalizowanej naukowo narracji. Dlatego można nazwać model uprawianej sztuki kontestującą w ujęciu konfrontacyjnym - sztuką podającą w wątpliwość, kwestionującą możliwy ład i rzeczywistość. Konfrontowanie rozumiane nie jako stawanie na barykadzie, pisanie nowych scenariuszy społecznych czy też manifestów politycznych, ale jako zestawianie utartych schematów myślowych z wrażliwością, odczuwaniem i wyobrażeniem społecznym artystów. To tematycznie teatr niezgody, ale i obserwacji, łamania dotychczasowych stylistyk czy również operowanie sprawdzonymi technikami teatralnymi.

Polska sztuka sceniczna ostatnich lat poszerza swoje kręgi zainteresowań. Ważnymi punktami stają się: cielesność, ukazywanie odmienności, patologii społecznych i polemizowanie z utartymi poglądami odnoszącymi się do kwestii wiary, tożsamości, patriotyzmu, seksualności i szeroko ujętej problematyki społecznej. Jednym z najważniejszych punktów odniesienia pozostaje szeroko rozumiane życie polityczne. To teatr wchodzący w spór ze światem wartości moralnych, które mają prawo podlegać krytyce twórcy, będącego częścią wspólnoty społecznej jak każdy inny obywatel. Analogicznie jak w przypadku sztuk wizualnych, w ostatnich latach owa

teatralnej i formach aktywności artystycznej, ukazującej metaforycznie, również aluzyjnie, stosunek twórcy (twórców) do rzeczywistości społecznej. Sam termin teatr polityczny został wprowadzony przez Erwina Piscatora, który oddał scenę na usługi bieżącej polityki, czerpiąc z najnowszej sztuki i cywilizacji. Zob. E. Piscator, Teatr polityczny, Warszawa 1982. Według słownikowego ujęcia, teatr polityczny to: „teatr zajmujący się konkretnymi wydarzeniami politycznymi i reprezentujący wobec nich określone stanowisko. Twórcy uprawiający ten rodzaj teatru posługują się bardzo różnymi środkami inscenizacyjnymi i różnego rodzaju tekstami. [...] Radykalną odmianę teatru politycznego stanowi agit-pop, teatr agitacyjny. [...] Teatr polityczny w szerokim, przenośnym znaczeniu to utwory i realizacje sceniczne ukazujące mechanizmy życia politycznego, dotyczące moralnych aspektów władzy itp. Za pomocą analizy [...] nakłaniają widza do politycznego myślenia o rzeczywistości”. M. Semil, E. Wysińska, Stownik współczesnego teatru. Twórcy, teatry, teorie, Warszawa 1990, s. 357.

${ }^{50}$ Jako jedną z nich można wskazać aktywność w teatrze alternatywnym czy studenckim, który choć finansowany z pieniędzy publicznych, wykazywał większą autonomię artystyczną niż teatry instytucjonalne. Nie należy całego okresu Polski Ludowej rozpatrywać jako jednorodnego życia teatralnego. Charakteryzowała go zmienność względem ukazywania problematyki aktualnej czy też dnia codziennego.

${ }^{51}$ Por. P. Mościcki, Teatr angażujacy [w:] program festiwalu Express EC 47. Odcienie polity$k i$, Warszawa 2006, s. 5. 
aktywność teatralna poddawana była licznym obostrzeniom i próbom ograniczania swobody twórczej. A przecież właśnie wolność to nadrzędna i najcenniejsza wartość państw i społeczeństw demokratycznej Europy.

Katalog twórców jest faktycznie nieograniczony. Dla przykładu można wskazać tych, co realizują spektakle w przestrzeni europejskiej, operując jasną, wyrazistą kreską inscenizacji: Krystian Lupa, Maja Kleczewska, Barbara Wysocka, Michał Zadara, Krzysztof Warlikowski, Jan Klata, Grzegorz Jarzyna, Krzysztof Garbaczewski, Michał Borczuch, Monika Strzępka, Ewelina Marciniak i wielu, wielu innych.

\section{Podsumowanie}

Cechą wyróżniającą - co starano się udowodnić - polskiego życia teatralnego zarówno instytucjonalnego, jak i artystycznego jest polityczny charakter. To zapewne jeden z najbardziej charakterystycznych elementów naszej sceny na mapie teatralnej demokratycznej Europy. Polska sztuka sceniczna stanowi ważny wkład w kulturę naszego kontynentu. Rozpatrując zagadnienie wymiaru europeizacji kultury (węziej - teatru), można zauważyć brak takich poczynań, jak choćby dla sfery edukacji - implementacji procesu bolońskiego, tworzenie wspólnych ram prawnych dla szkolnictwa podstawowego i średniego czy pisanie wspólnych podręczników ${ }^{52}$. Odnosząc zjawisko europeizacji, zgodnie z tezą opracowania, do form organizacyjnych, finansowania i współpracy międzynarodowej, dostrzegamy, że następuje przyjmowanie norm, zwyczajów i standardów europejskich do polskiej sfery kultury. Zauważalne jest to poprzez: demokratyzację organizacji życia teatralnego, decentralizację (choć ułomną), wykorzystanie środków unijnych czy współpracę międzynarodową. To również gwarancje dla wolności wypowiedzi artystycznej - standardu państw demokratycznej Europy, choć u nas nacechowane są próbami jej hamowania i ograniczania. Ze względu na dominację w naszym kraju sfery polityki w zarządzaniu życiem teatralnym implementowanie uniwersalnych wartości i zasad to nieustający proces zmian oraz aktywności w celu konstruowania wspólnej kultury europejskiej, której Polska jest nieodłączną częścią.

\section{Bibliografia}

\section{Materiały źródłowe publikowane:}

Europejska Konwencja Kulturalna z dnia 19 grudnia 1954 roku, Dz.U. 1990 nr 8 poz. 44.

Obwieszczenie Marszałka Sejmu Rzeczypospolitej Polskiej z dnia 8 czerwca 2010 w sprawie ogłoszenia jednolitego tekstu Ustawy - Prawo zamówień publicznych (Ustawa z dnia 29 stycznia 2004 roku - Prawo zamówień publicznych), Dz.U. 2010 nr 113 poz. 759.

52 Szerzej: K. Wach, Wymiary europeizacji i jej kontekst..., s. 33-36. 
Obwieszczenie Marszałka Sejmu Rzeczypospolitej Polskiej z dnia 26 marca 2012 w sprawie ogłoszenia jednolitego tekstu ustawy o organizowaniu i prowadzeniu działalności kulturalnej (Ustawa z dnia 25 października 1991 o organizowaniu i prowadzeniu działalności kulturalnej), Dz.U. 2012 poz. 406.

Rozporzadzenie Ministra Kultury z dnia 1 września 2005 r. w sprawie zakresu zadań objętych mecenatem państwa, szczególowego trybu składania wniosków o udzielenie dotacji oraz trybu przekazywania i rozliczania udzielonych dotacji, Dz.U. $2005 \mathrm{nr} 177$ poz. 1474.

Rozporzadzenie Ministra Kultury i Dziedzictwa Narodowego z dnia 26 lipca 2012 r. w sprawie samorzadowych instytucji kultury, w których wytonienie kandydata na stanowisko dyrektora następuje w drodze konkursu, Dz.U. 2012 poz. 889.

\section{Strony internetowe:}

www.ec.europa.eu.

www.etc-cte.org.

www.fabulamundi.eu.

www.mitos21.com.

www.mkidn.gov.pl.

www.opera-europa.org.

www.stary.pl.

www.union-theatres-europe.eu.

\section{Artykuły i opracowania:}

Bańka Z., Kajzer M., Kluza S., Suder D. (oprac.), Główny Urząd Statystyczny, Urząd Statystyczny w Krakowie, Działalność instytucji kultury w Polsce w 2013 roku, file:///C:/Users/UW D/ Downloads/dzialalnosc_instytucji_kultury_w_polsce_w_2013.pdf [odczyt: 15.08.2014].

Bińczycka E., Czwartkowska M., Jędrychowska B., Kluza S., Plata M. (oprac.), Główny Urząd Statystyczny, Urząd Statystyczny w Krakowie, Działalność instytucji kultury w Polsce w 2012, http://stat.gov.pl/cps/rde/xbcr/gus/KTS_dzialalnosc_instyt_kultury_w_polsce_2012.pdf [odczyt: 18.08.2014].

Badanie publiczności teatrów stolicy. Raport, Warszawa 2013.

Braun K., Wielka Reforma Teatru w Europie, Wrocław 1984.

Braun K., Kieszonkowa historia teatru na świecie w XX wieku, Lublin 2000.

Brown J.R. (red.), Historia teatru, Warszawa 2007.

Dąbrowski W., Wielki czas budowania, rozmawiali Długosz K. i Domański J., „Przegląd” 2005, nr 29.

Flejterski S., Roszkowska E. (red.), Teatry w Europie. II międzynarodowa konferencja: teatr - otoczenie społeczne, prawne i finansowe, Szczecin 2004.

Fryz-Więcek A., Wróblewski S. (red.), Mitos 21. Antologia, t. I i II, Kraków 2012.

Gierat-Bieroń B., Kowalski K. (red.), Europejskie modele polityki kulturalnej, t. 1, Kraków 2005.

Gierat-Bieroń B. (red.), Europejskie modele polityki kulturalnej, t. 2, Kraków 2006.

Goffman E., Człowiek w teatrze życia codziennego, Warszawa 1981.

Hieropolitańska A., Rola K. (red), Program Kultura 2007-2013 w Polsce. Analiza i podsumowanie, Warszawa 2013.

Kutyła J., Walaszkowski P. (red.), Pawlenski, Warszawa 2016.

Mecenat pelnowymiarowy. Polityka kulturalna państwa 2005-2007, Warszawa 2007.

Ministerstwo Kultury i Dziedzictwa Narodowego, Działania MKiDN w latach 2007-2015, Warszawa 2015.

Mościcki P., Teatr angażujący [w:] Program festiwalu Express EC 47. Odcienie polityki, Warszawa 2006.

Piscator E., Teatr polityczny, Warszawa 1982. 
Płoski P., Przemiany organizacyjne teatru $w$ Polsce $w$ latach 1989-2009, Warszawa 2009, http://www.kongreskultury.pl/library/File/RaportTeatr/teatr_raport_w.pelna(1).pdf [odczyt: 25.07.2017].

Przastek D., Europejska wspótpraca kulturalna. Unia Teatrów Europy, „Przegląd Europejski” 2002, $\mathrm{nr} 2$.

Przastek D., Ograniczenia wolności wypowiedzi artystycznej w Polsce po roku 1989. Przypadek teatru, „Kwartalnik Naukowy OAP UW e-Politikon” 2016, nr 18.

Przastek D., Polityka kulturalna w Polsce (i na świecie), „Studia BAS” 2016, nr 2.

Prykowska-Michalak K. (red.), System organizacji teatrów w Europie, Warszawa 2016.

Wach K., Wokół pojęcia europeizacji, „Horyzonty Polityki” 2010, nr 1.

Wach K., Wymiary europeizacji i jej kontekst, Zeszyty Naukowe Uniwersytetu Ekonomicznego w Krakowie 2011, nr 852.

Schechner R., Performatyka. Wstęp, Wrocław 2006.

Semil M., Wysińska E., Słownik wspótczesnego teatru. Twórcy, teatry, teorie, Warszawa 1990.

Smoleń M., Nowa perspektywa finansowa 2007-2013 - perspektywy dla kultury, „Zarządzanie Publiczne" 2005, nr 1.

Sulowski S., Państwo narodowe w procesie integracji europejskiej [w:] Wojtaszczyk K.A. (red.), Integracja europejska. Wstep, Warszawa 2006.

Szum M., Zarys struktury organizacyjnej teatrów Wielkiej Brytanii-wybrane aspekty ich finansowania i funkcjonowania [w:] Mazurek-Łopacińska K. (red.), Kultura polska a Unia Europejska. Problemy, wyzwania, nadzieje, Warszawa-Wrocław 1998.

Traktat Lizboński, Sozański J. (wprowadzenie), Warszawa-Poznań 2010.

13 Europejska Nagroda Teatralna, katalog, M. Giovanelli (red.), Wrocław 2009.

15th Europe Theatre Prize, katalog, L. Mususmarra (red.), Craiova 2016. 